\title{
Croatian population and clinical epidemiologic studies (1995-2011); the use of $A B C$ score and gradual progress of cardiosurgical model in developing countries
}

\author{
I Malčić, D Dilber, D Šarić, H Kniewald, D Bartoniček, D Anić, D Belina, A Hodalin, S Dorner, N Čače, V Metličić, \\ K Markičević, M Sršen-Krstulović
}

From 23rd World Congress of the World Society of Cardio-Thoracic Surgeons

Split, Croatia. 12-15 September 2013

\section{Summary}

The treatment of the children with congenital heart disease (CHD) is not the same in different parts of the world. In Europe, a patway for international cooperation in the field of care for children with CHD is not yet well established, and higly dependent on national structures and cooperation. We established the Register of CHD in Croatia using the priciples of EUROCAT, with the aim to study the distribution of $\mathrm{CHD}$ and outcome analysis. The prevalence of CHD in two different periods (January 1. 1995- December 31. 2000 and January 1. 2002- Dezember 31.2007 ) was 0.8 and $0.72 \%$. By employing the widely used and accepted methodologies of case mix complexity adjustment in congenital cardiac surgery, together with collecting data in EUROCAT Registry and European Association for Cardio-Thoracic Surgery Database (EACTS), we tried to study surveillance of children in Croatia and to evaluate our performance. All children born in Croatia between January first 2003 and December 31. 2013 with diagnosis of CHD were included. Case mix complexity adjustement of cardiac operation is performed by using the Aristotel basic complexity score. During study 1034 patients were operated and 1278 operatins performed. Among 641 operations performed in Croatia 25 children died during or as a result of operations, that gives $3.9 \%$ of early miortality. The mean complexity for cardiac procedures peroformed in Croatia is 5.9. More complex operations were perfomed in foreigen centres with $\mathrm{ABC}$ score more between 6-15 and early

Clinical Hospital Centre Zagreb, Department of Paediatric Cardiology and Department of Cardiac Surgery, Zagreb, Croatia mortality score less than $5 \%$. During the last 4 years of the study, the number of operations performed in Croatia showed linear increase: 55, 78, 121 and 126 operations were performed in 2008, 2009, 2010 an 2011, rrespectively.

\section{Conclusion}

Further initiatives have to be done, to improve the services provided on a national level and also to develop cooperation between neghboring small countries.

Published: 11 September 2013

doi:10.1186/1749-8090-8-S1-0117

Cite this article as: Malčić et al:: Croatian population and clinical epidemiologic studies (1995-2011); the use of ABC score and gradual progress of cardiosurgical model in developing countries. Journal of Cardiothoracic Surgery 2013 8(Suppl 1):0117.

Submit your next manuscript to BioMed Central and take full advantage of:

- Convenient online submission

- Thorough peer review

- No space constraints or color figure charges

- Immediate publication on acceptance

- Inclusion in PubMed, CAS, Scopus and Google Scholar

- Research which is freely available for redistribution 